\title{
Isotopic ages of Jurassic siliceous shale and Triassic bedded chert in Unuma, Central Japan
}

\author{
Ken Shibata ${ }^{1}$ and Shinjiro Mizutani ${ }^{2}$ \\ Geological Survey of Japan, Yatabe, Ibaraki $305,{ }^{1}$ and \\ Department of Earth Sciences, Nagoya University, Nagoya $464,{ }^{2}$ Japan
}

(Received April 21, 1982: Accepted September 11, 1982)

\begin{abstract}
Isotopic age determinations were carried out for Jurassic siliceous shale (assigned to Bajocian by radiolarian fossils) and for Triassic bedded chert (assigned to Anisian by radiolarians and conodonts) in Unuma, Gifu Prefecture, Central Japan. Whole-rock samples of the Jurassic shale give a Rb-Sr isochron age of $179.8 \pm 5.7 \mathrm{Ma}$ with an initial ${ }^{87} \mathrm{Sr} /{ }^{86} \mathrm{Sr}$ ratio of $0.71011 \pm 0.00036$, whereas two of these Jurassic samples have K-Ar whole-rock ages of 151 and $152 \mathrm{Ma}$. For the Triassic chert, the Rb-Sr whole-rock isochron shows $211.9 \pm 4.7 \mathrm{Ma}$ with an initial ${ }^{87} \mathrm{Sr} /{ }^{86} \mathrm{Sr}$ ratio of $0.71325 \pm 0.00020$, and a K-Ar wholerock age for one of these Triassic samples is $207 \pm 7 \mathrm{Ma}$.

Two $\mathrm{Rb}-\mathrm{Sr}$ whole-rock isochron ages indicate the time when the respective sedimentary rocks became chemically closed with regard to the $\mathrm{Rb}-\mathrm{Sr}$ system. The initial ${ }^{87} \mathrm{Sr} /{ }^{86} \mathrm{Sr}$ ratios in both sets of rocks are higher than the contemporaneous marine ${ }^{87} \mathrm{Sr} /{ }^{86} \mathrm{Sr}$ ratio, suggesting the existence of an older landmass. The K-Ar ages of the Jurassic siliceous shale presumably represent the time of a later geologic event.
\end{abstract}

\section{INTRODUCTION}

We reported isotopic ages of Jurassic siliceous shale in Hida-Kanayama, Central Japan (Shibata and Mizutani, 1980). The result shows that the whole-rock system yields a $\mathrm{Rb}-\mathrm{Sr}$ isochron age of $128 \pm 3 \mathrm{Ma}$, whereas the deposition age assigned by radiolarian fossils to be early Tithonian is geochronologically about $145 \mathrm{Ma}$, if we adopt a time scale summarized by ARMSTRONG and MCDOWALL (1974). The difference between the isotopic age and the fossil age is ascribed to a time-span during which the sedimentary rocks underwent diagenesis until they became chemically closed with respect to the $\mathrm{Rb}-\mathrm{Sr}$ system.

This result has urged us to examine another example from the same viewpoint. In Central Japan, we have a large amount of paleontological data ranging in age from Permian to Jurassic found in limestone, chert and siliceous shale, among which we selected two sets of specimens from an exposure in Unuma; one is Jurassic siliceous shale carrying abundant radiolarian remains, and the other Triassic bedded chert containing conodonts as well as radiolarians. In this paper we report the results of $\mathrm{Rb}-\mathrm{Sr}$ and $\mathrm{K}-\mathrm{Ar}$ whole-rock analyses and discuss the applicability of isotopic dating to sedimentary rocks. Paleontological and biostratigraphical study on the Jurassic shale and the Triassic chert described here is published in a separate paper (MizuTANi and KoIKe, 1982).

\section{Geologic Setting}

Samples for the isotopic age determinations were collected from an exposure along the Kiso River, Unuma, Kagamigahara City, Gifu Prefecture, Central Japan (1 at. $35^{\circ} 23^{\prime} 42^{\prime \prime} \mathrm{N}$, long. $\left.136^{\circ} 57^{\prime} 40^{\prime \prime} \mathrm{E}\right)$. Geological investigations of this area have been carried out by HAYASHI and INOUE (1962), and Kondo and ADACHI (1975), and paleontological study has been done by YAO (1972), and ICHIKAWA and YAO (1976). 


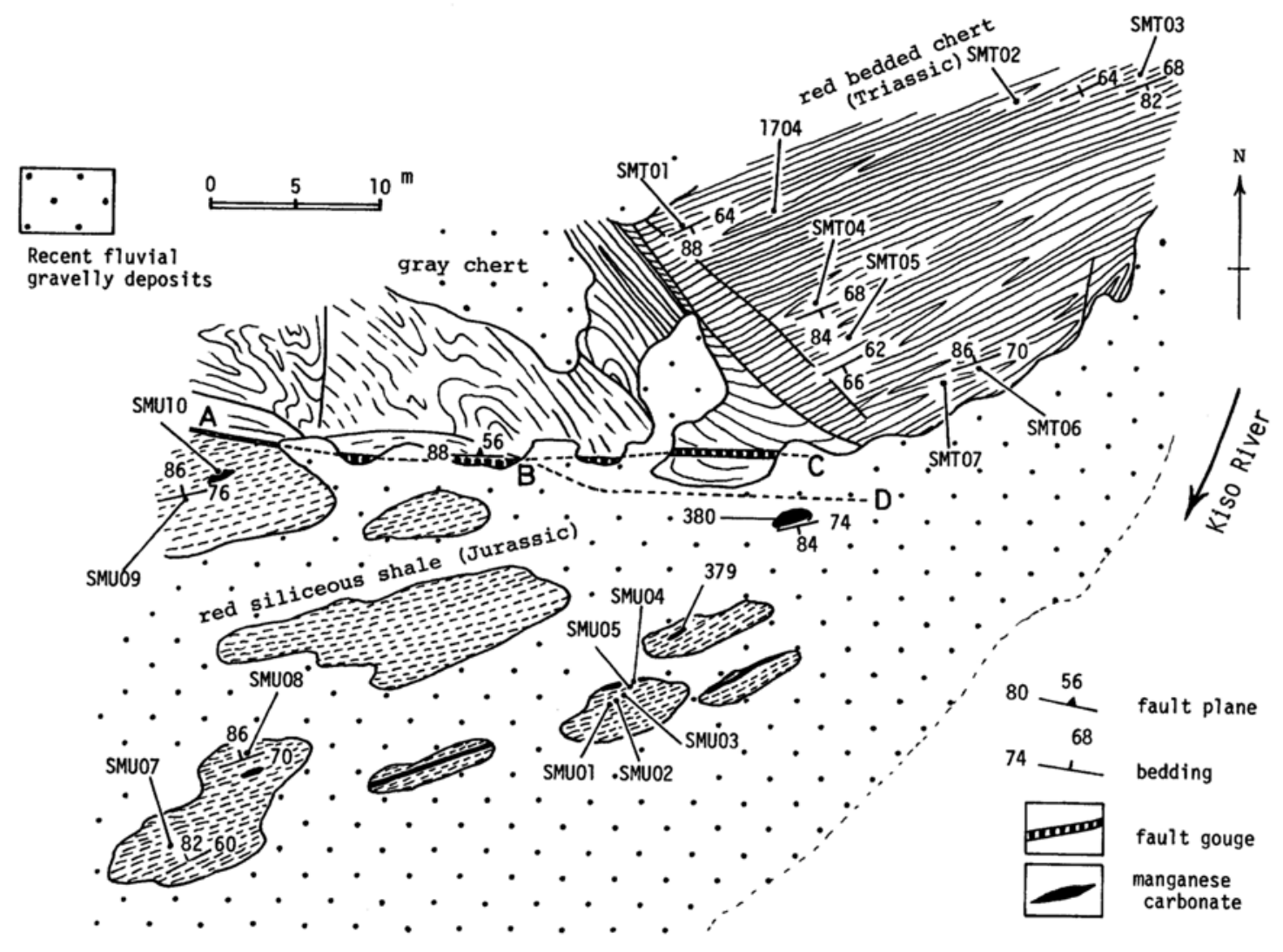

Fig. 1 Geologic map of the studied area (Unuma, Kagamigahara City, Gifu Prefecture) showing locations of samples for geochronological study. Samples 379 and 380 only for paleontological study (see MIZUTANI and KOIKE, 1982).

As shown in Fig. 1, siliceous shale is exposed in the southern part of the studied area, intermittently covered by recent gravelly deposits. This shale intercalates layers and nodules of manganese carbonate (rhodochrosite). Radiolarian fossils are abundantly contained in both of these siliceous and carbonate rocks. By referring to the radiolarian biostratigraphy described by Pessagno and Blome (1980), they are indicative of the Bajocian (MIZutani and KoIKe, 1982). Apparently the siliceous shale dips steeply to the north, its thickness being estimated at about $25 \mathrm{~m}$ (Fig. 2).

Bedded chert is exposed in the northern part of the studied area exhibiting remarkable intraformational folds. Geometric reconstruction of this structure as demonstrated by MizUTANI and KoIKE (1982) gives a result that the red bedded chert is about $9 \mathrm{~m}$ thick (Fig. 2). The Triassic rocks studied contain abundantly radiolarian remains and infrequently conodont fossils. All the conodont elements, extracted by repeated treatment of fragments of the rocks with $10-15 \%$ hydrofluoric acid solution for several hours, are light gray to very light gray and not transparent. The radiolarian fossils in the red bedded chert are very similar to those of the Buchenstein Formation in southern Alps (Anisian-Ladinian in age) described by Dumitrica et al. (1980). Mizutani and KoIKE (1982), however, concluded that the bedded chert is referable to the Anisian, judging from the presence of Neogondolella bulgarica.

An E-W trending fault gouge is found between the Jurassic siliceous shale and the Triassic bedded chert. At point B in Fig. 1, we can 
observe a slickensided surface. This fault runs from $\mathrm{A}$ to $\mathrm{B}$ between two formations different in lithology, but from B to $\mathrm{C}$ it goes through the chert. A lithological boundary between the Jurassic siliceous shale and the Triassic bedded chert extends from B to D, although the contact cannot be observed owing to gravelly deposits. The original relation prior to faulting is utterly unknown here. It is highly probable that the Triassic bedded chert came into contact with the Jurassic shale under a sedimentary condition as studied by Matsuda et al. (1981, in MizUtani et al., 1981 b) at an exposure about $1 \mathrm{~km}$ north to this outcrop.

Sampling points for our geochronological study are shown in Fig. 1 and those of paleontological study are also shown in reference to the paper reported by Mizutani and KoIKE (1982).

\section{Analytical Procedures}

All the samples for isotopic age determinations were taken directly from outcrops. Since rock formations are exposed on a river bank, and hence a weathered part on the surface is removed at all times by flood water, the outcrops have every appearance of being fresh. Yet, we excluded surfacial parts and collected fresh and homogeneous chips and fragments ranging in size from $5 \mathrm{~mm}$ to $3 \mathrm{~cm}$ free from veinlets wide enough to be seen with the naked eye for $\mathrm{Rb}-\mathrm{Sr}$ whole-rock analysis. Much larger samples about $5 \mathrm{~cm}$ in diameter were taken for $\mathrm{K}-\mathrm{Ar}$ whole-rock analysis.

$\mathrm{Rb}$ and $\mathrm{Sr}$ concentrations were measured by either X-ray fluorescence or isotopic dilution analysis. The ${ }^{87} \mathrm{Sr} /{ }^{86} \mathrm{Sr}$ ratios were measured by a Micromass 54E mass spectrometer. All ${ }^{87} \mathrm{Sr} /{ }^{86} \mathrm{Sr}$ ratios were normalized to ${ }^{86} \mathrm{Sr} /{ }^{88} \mathrm{Sr}$ ratio $=0.1194$. Repeated analyses of the $\mathrm{E}$ and A standard during this study gave a ${ }^{87} \mathrm{Sr} /{ }^{86} \mathrm{Sr}$ ratio of $0.70805 \pm 0.00002(1 \sigma)$. We calculated the isochron ages with the least-square method of YoRK (1966), taking account of $\pm 3 \%$ and \pm $5 \%$ error in ${ }^{87} \mathrm{Rb} /{ }^{86} \mathrm{Sr}$ ratio for isotopic dilution and X-ray fluorescence, respectively, and \pm
$0.015 \%$ in ${ }^{87} \mathrm{Sr} /{ }^{86} \mathrm{Sr}$ ratio. Errors in age and intercept were given on $2 \sigma$ level. $\mathrm{K}$-Ar age determinations were carried out on two samples of the Jurassic siliceous shale and one sample of the Triassic bedded chert in order to compare the results with the $\mathrm{Rb}-\mathrm{Sr}$ whole-rock isochron ages. The analytical method is essentially the same as described by Shibata et al. (1971). The decay constants used for age calculation are: ${ }^{87} \mathrm{Rb}=1.42 \times 10^{-11} / \mathrm{y},{ }^{40} \mathrm{~K} \lambda_{\beta}=4.962 \times 10^{-10} / \mathrm{y}$, ${ }^{40} \mathrm{~K} \lambda_{\mathrm{e}}=0.581 \times 10^{-10} / \mathrm{y},{ }^{40} \mathrm{~K} / \mathrm{K}=0.01167$ atom $\%$. Errors are given on $1 \sigma$ level.
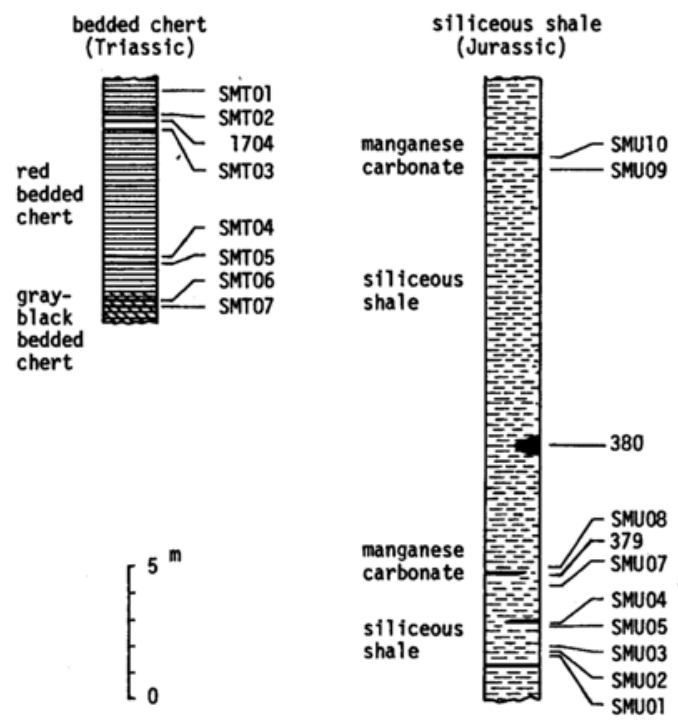

Fig. 2. Geologic sections of Jurassic siliceous shale and Triassic bedded chert showing stratigraphic positions of samples for geochronological study. Samples 379 and 380 only for paleontological study (see MIZUTANI and KOIKE, 1982).

\section{RESULTS}

Jurassic siliceous shale: $-\mathrm{Rb}-\mathrm{Sr}$ and $\mathrm{K}-\mathrm{Ar}$ analytical results for the siliceous shale are listed in Tables 1 and 3, respectively. Rb-Sr data for whole-rock samples give an isochron age of $179.8 \pm 5.7(2 \sigma)$ Ma by excluding sample SMU04, which is clearly far off the rectilinear plot (Fig. 3).

According to a time scale presented by ARMSTRONG and MCDOWALl (1974), 179.8 $\pm 5.7 \mathrm{Ma}$ is correlated to the Aalenian-Toarcian age. The isochron plot of Fig. 3 gives the initial 
${ }^{87} \mathrm{Sr} /{ }^{86} \mathrm{Sr}$ ratio for the siliceous shale, $\mathrm{R}_{\mathrm{o}}=$ $0.71011 \pm 0.00036(2 \sigma)$, higher than that of contemporaneous marine $\mathrm{Sr}(0.707)$ estimated by Peterman et al. (1970).

$\mathrm{K}$-Ar ages for two samples listed in Table/3 are 152 and $151 \mathrm{Ma}$, and significantly younger than the $\mathrm{Rb}-\mathrm{Sr}$ isochron age.

Triassic bedded chert: - The analytical results for the bedded chert are shown in Tables 2 and 3. In Fig. 4, Rb-Sr data for seven wholerock samples fall on an isochron of $211.9 \pm 4.7$

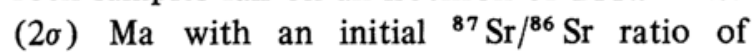
$0.71325 \pm 0.00020(2 \sigma)$. One sample (SMT06) is excluded in calculation of the whole-rock isochron age, because this sample solely lies far off the rectilinear plot. The initial ${ }^{87} \mathrm{Sr} /{ }^{86} \mathrm{Sr}$ ratio for the Triassic bedded chert is also much higher than that of contemporaneous marine Sr (Peterman et al., 1970). On the time scale of ARMSTRONG and McDowall (1974), the age of $211.9 \mathrm{Ma}$ corresponds almost to the Triassic and Jurassic boundary.

A K-Ar age for one sample of red bedded

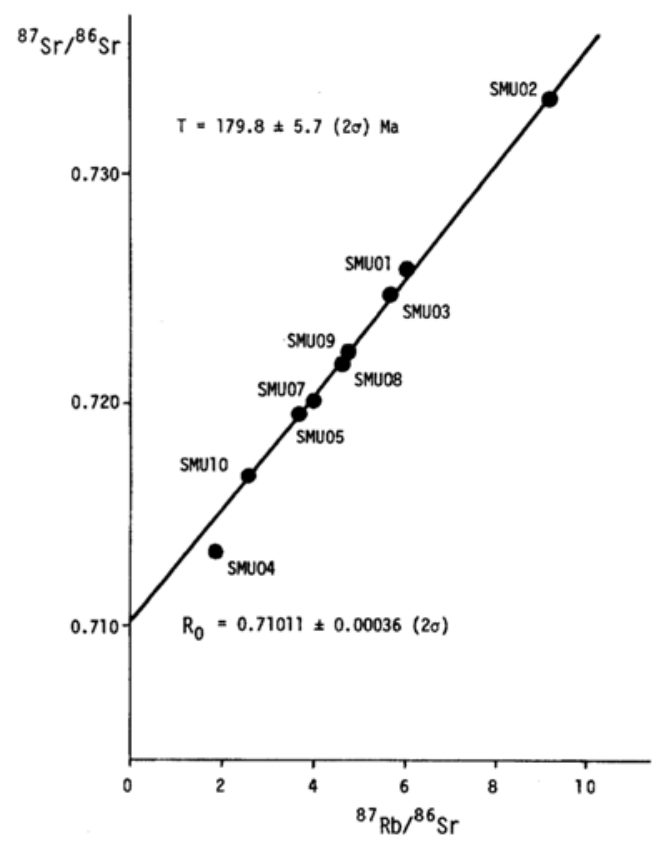

Fig. 3. Rb-Sr whole-rock isochron plot of Jurassic siliceous shale. chert, $207 \pm 7 \mathrm{Ma}$, is nearly equal to the $\mathrm{Rb}-\mathrm{Sr}$ whole-rock isochron age.

\section{Discussion}

Although one exceptional sample is located off the $\mathrm{Rb}-\mathrm{Sr}$ whole-rock isochron in each set of samples (Figs. 3 and 4), the rectilinear relationship between ${ }^{87} \mathrm{Rb} /{ }^{86} \mathrm{Sr}$ and ${ }^{87} \mathrm{Sr} /{ }^{86} \mathrm{Sr}$ suggests the adequacy of this method for the age determination. In this kind of fine-grained sediments, isotopic homogenization must have started immediately after deposition of the sediments, keeping different $\mathrm{Rb} / \mathrm{Sr}$ ratios as exemplified by CORDANI et al. (1978) on the analytical results presented by DASCH (1969) or BISCAYE and DASCH (1971), and to be accomplished supposedly at the end of chemical diagenesis when the whole-rock system was closed with respect to the chemical species concerned. Probably radiogenic ${ }^{87} \mathrm{Sr}$ is the mobile component in the $\mathrm{Rb}-\mathrm{Sr}$ system, and responsible for $\mathrm{Sr}$ isotopic homogenization.

We have calculated the age result for the Jurassic siliceous shale excluding sample SMU04.

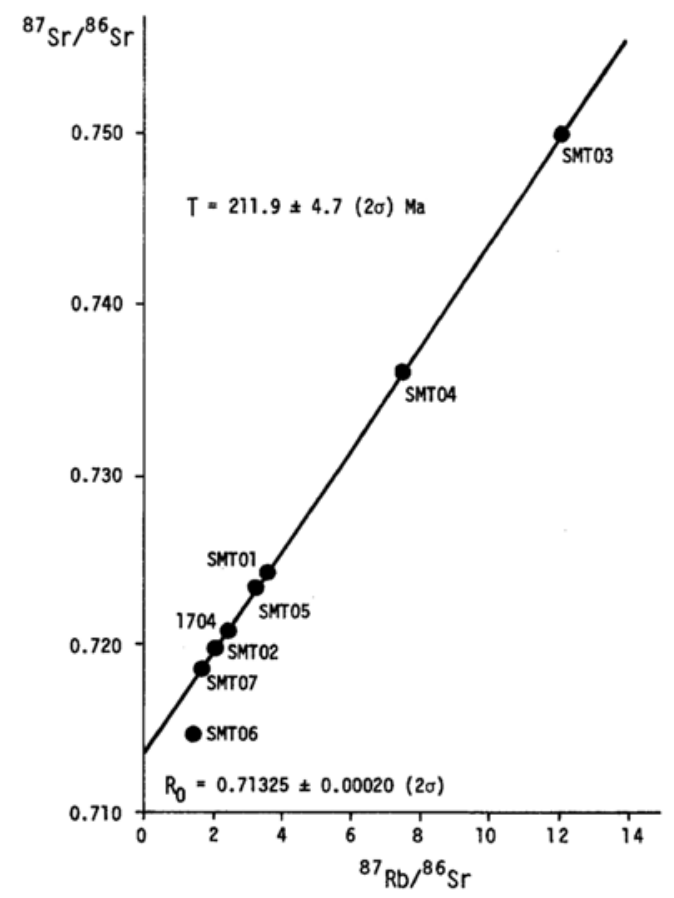

Fig. 4. Rb-Sr whole-rock isochron plot of Triassic bedded chert. 
Table 1. Rb-Sr analytical data for Jurassic siliceous shale from Unuma, Gifu Prefecture, Central Japan

\begin{tabular}{l|lcccc}
\hline \hline Sample No. & \multicolumn{1}{|c}{ Rock } & $\begin{array}{c}\mathrm{Rb} \\
(\mathrm{ppm})\end{array}$ & $\begin{array}{c}\mathrm{Sr} \\
(\mathrm{ppm})\end{array}$ & ${ }^{87} \mathrm{Rb} /{ }^{86} \mathrm{Sr}$ & ${ }^{87} \mathrm{Sr} /{ }^{86} \mathrm{Sr}$ \\
\hline SMU01 & siliceous shale & 85.81 & 41.27 & 6.021 & 0.72591 \\
SMU02 & siliceous shale & 108.7 & 34.27 & 9.181 & 0.73336 \\
SMU03 & siliceous shale & $104^{*}$ & $53.2^{*}$ & 5.66 & 0.72436 \\
SMU04 & manganese carbonate & $51.6^{*}$ & $80.6^{*}$ & 1.85 & 0.71331 \\
SMU05 & siliceous shale & $79.0^{*}$ & $62.3^{*}$ & 3.67 & 0.71948 \\
& & & & & \\
SMU07 & siliceous shale & $88.5^{*}$ & $64.2^{*}$ & 3.99 & 0.72010 \\
SMU08 & siliceous shale & $97.6^{*}$ & $61.2^{*}$ & 4.62 & 0.72177 \\
SMU09 & siliceous shale & $76.4^{*}$ & $46.8^{*}$ & 4.73 & 0.72214 \\
SMU10 & manganese carbonate & 21.06 & 23.51 & 2.593 & 0.71677 \\
\hline
\end{tabular}

* X-ray fluorescence analysis

Table 2. Rb-Sr analytical data for Triassic bedded chert from Unuma, Gifu Prefecture, Central Japan

\begin{tabular}{c|lcccc}
\hline Sample No. & \multicolumn{1}{|c}{ Rock } & $\begin{array}{c}\mathrm{Rb} \\
(\mathrm{ppm})\end{array}$ & $\begin{array}{c}\mathrm{Sr} \\
(\mathrm{ppm})\end{array}$ & ${ }^{87} \mathrm{Rb} /{ }^{86} \mathrm{Sr}$ & ${ }^{87} \mathrm{Sr} /{ }^{86} \mathrm{Sr}$ \\
\hline \multirow{2}{*}{ SMT01 } & red bedded chert & 29.15 & 23.28 & 3.626 & 0.72410 \\
SMT02 & red bedded chert & 28.57 & 39.40 & 2.100 & 0.71973 \\
SMT03 & red shale in bedded chert & 157.8 & 37.77 & 12.10 & 0.74969 \\
SMT04 & red shale in bedded chert & 142.0 & 54.87 & 7.497 & 0.73579 \\
SMT05 & red bedded chert & 40.42 & 35.62 & 3.286 & 0.72327 \\
SMT06 & gray chert & $20.8 *$ & $40.5 *$ & 1.49 & 0.71453 \\
SMT07 & black chert & 14.22 & 23.73 & 1.735 & 0.71840 \\
1704 & red bedded chert & 21.33 & 24.70 & 2.501 & 0.72071 \\
\hline
\end{tabular}

* X-ray fluorescence analysis

Table 3. K-Ar ages of Jurassic siliceous shale and Triassic bedded chert from Unuma, Gifu Prefecture, Central Japan

\begin{tabular}{|c|c|c|c|c|c|}
\hline Sample No. & Rock & $\begin{array}{l}\mathrm{K}_{2} \mathrm{O} \\
(\%)\end{array}$ & $\begin{array}{c}{ }^{40} \mathrm{Ar} \mathrm{rad} \\
\left(10^{-6} \mathrm{ml} / \mathrm{g}\right)\end{array}$ & $\underset{(\%)}{\operatorname{Atm} .{ }^{40} \mathrm{Ar}}$ & $\begin{array}{l}\text { Age } \\
\text { (Ma) }\end{array}$ \\
\hline SMU05 & siliceous shale & 1.50 & 7.66 & 21.1 & $152 \pm 5$ \\
\hline \multirow[t]{3}{*}{ SMU07 } & siliceous shale & 1.85 & 9.45 & 20.8 & $151 \pm 5$ \\
\hline & & & 9.37 & 16.7 & $150 \pm 5$ \\
\hline & & & & & $151 \pm 4$ \\
\hline 1704 & red bedded chert & 0.504 & 3.57 & 22.2 & $207 \pm 7$ \\
\hline
\end{tabular}


This sample contains manganese carbonate spherules, a few millimeters in diameter, embedded in a siliceous argillaceous matrix. Radiolarian skeletons are frequently contained in the carbonate spherules, but they are scarcely found in the matrix. As to the radiolarian remains, sample SMU04 is rather heterogeneous in composition. It is very likely that the $\mathrm{Sr}$ isotopic homogenization was not completed at the time when the whole rock was chemically closed with respect to the $\mathrm{Rb}-\mathrm{Sr}$ system. On the other hand, the remaining samples suggest that the homogenization took place at that time.

Since the sedimentation rate of chert is much lower than that of mudstone or shale, the sediments should have time sufficient for the homogenization after they were laid down. Nevertheless, sample SMT06 does not fall on the whole-rock isochron in Fig. 4. The sample consists mostly of cryptocrystalline quartz, and is different from other samples in color; it is medium gray, whereas most of the samples falling on the isochron in Fig. 4 are grayish red. The reason why this sample possesses a particular geochemical property different from the other ones in the Triassic bedded chert is really a bewildering question. It may be attributed to a later alteration, which took place through fine veinlets usually developed perpendicular to the bedding of this sample. In fact, just above sample SMT06, about $9 \mathrm{~cm}$ apart from the sample in a direction perpendicular to the bedding, a thin layer of jaspilite is found to be intercalated in bedded chert. Microscopic examination has disclosed that the jaspilite consists of chalcedony and quartz crystal, and no trace of fossil remains is detected, strongly suggesting the jaspilite to have been formed inorganically at the later stage. The neighboring part of this jaspilite, probably covering the sample point of SMT06, had been placed to some extent in a particular chemical environment, in which silica minerals in the jaspilite precipitated, though extremely locally. At that stage of the jaspilite formation, it is highly probable that sample SMT06 was subjected more or less to an alteration accompanied by material transfer, and its chemical composition is in no way the same as the original one.

In addition to two examples mentioned above, we have one more $\mathrm{Rb}-\mathrm{Sr}$ whole-rock isochron age already reported by the present authors. The $\mathrm{Rb}-\mathrm{Sr}$ isotopic analyses of siliceous shale samples from Hida-Kanayama reveal that

Table 4. Isotopic ages of Upper Jurassic shale, Middle Jurassic shale and Middle Triassic chert from Central Japan

\begin{tabular}{|c|c|c|c|c|c|c|}
\hline & Locality & $\begin{array}{l}\text { fossil age } \\
\text { and } \\
\text { lithology }\end{array}$ & $\begin{array}{c}\mathrm{Rb}-\mathrm{Sr} \\
\text { whole-rock } \\
\text { isochron } \\
\text { age } \mathrm{Ma}\end{array}$ & $\begin{array}{l}\text { initial } \\
{ }^{87} \mathrm{Sr} /{ }^{86} \mathrm{Sr} \\
\text { ratio }\end{array}$ & $\begin{array}{c}\mathrm{K}-\mathrm{Ar} \\
\text { whole-rock } \\
\text { age } \mathrm{Ma}\end{array}$ & literature \\
\hline (a) & $\begin{array}{l}\text { Hida-Kanayama, } \\
\text { Gifu Prefecture }\end{array}$ & $\begin{array}{l}\text { Upper Jurassic } \\
\text { (Tithonian) } \\
\text { siliceous shale }\end{array}$ & $128 \pm 6$ & $\begin{array}{l}0.7155 \pm \\
0.0008\end{array}$ & $\begin{array}{l}125 \pm 4 \\
128 \pm 4 \\
130 \pm 4 \\
133 \pm 4 \\
157 \pm 4 \\
165 \pm 4\end{array}$ & $\begin{array}{l}\text { SHIBATA and } \\
\text { MIZUTANI (1980), } \\
\text { MIZUTANI (1981) }\end{array}$ \\
\hline (b) & $\begin{array}{l}\text { Unuma, Kagamigahara, } \\
\text { Gifu Prefecture }\end{array}$ & $\begin{array}{l}\text { Middle Jurassic } \\
\text { (Bajocian) } \\
\text { siliceous shale }\end{array}$ & $179.8 \pm 5.7$ & $\begin{array}{l}0.71011 \pm \\
0.00036\end{array}$ & $\begin{array}{l}151 \pm 4 \\
152 \pm 5\end{array}$ & $\begin{array}{l}\text { this paper, } \\
\text { MIZUTANI and } \\
\text { KOIKE (1982) }\end{array}$ \\
\hline (c) & $\begin{array}{l}\text { Unuma, Kagamigahara, } \\
\text { Gifu Prefecture }\end{array}$ & $\begin{array}{l}\text { Middle Triassic } \\
\text { (Anisian) } \\
\text { bedded chert }\end{array}$ & $211.9 \pm 4.7$ & $\begin{array}{l}0.71325 \pm \\
0.00020\end{array}$ & $207 \pm 7$ & $\begin{array}{l}\text { this paper, } \\
\text { MIZUTANI and } \\
\text { KOIKE (1982) }\end{array}$ \\
\hline
\end{tabular}


nine of ten analyses fall on an isochron representing an age of $128 \pm 3 \mathrm{Ma}$ (ShibATA and Mizutani, 1980).

As summarized in Table 4, all these sets of samples can be arranged in descending order of fossil ages as follows: set (a) siliceous shale in Hida-Kanayama, set (b) siliceous shale in Unuma, and set (c) bedded chert in Unuma, for which we have obtained the $\mathrm{Rb}-\mathrm{Sr}$ isochron ages of (a) $128 \mathrm{Ma}$, (b) $179.8 \mathrm{Ma}$, and (c) $211.9 \mathrm{Ma}$, respectively. The order of the fossil ages coincides, therefore, with that of the isotopic ages.

According to the paleontological and biostratigraphical studies by MizuTANI (1981) and Mizutan I and KoIKE (1982), these strata are (a) Tithonian, (b) Bajocian, and (c) Anisian in age, respectively. If we adopt the time scale of ARMSTRONG and McDowall (1974) for these geological ages, it gives ages of approximately (a) $145 \mathrm{Ma}$, (b) $175 \mathrm{Ma}$, and (c) $240 \mathrm{Ma}$. Shibata and Mizutani (1980) explained the time difference between the fossil age and the isotopic age for set (a) by a time-span during which the sediments underwent lithification, the isotopic age signifying the end of chemical diagenesis.

Chemical diagenesis is governed essentially by temperature, time and chemical environment, and the process continues with time. Even when the process takes place in sediments, which are chemically similar to one another, the progressive stage of diagenetic change is not the same for them, but depends upon the thermal history (Mizutani, 1970, 1977; Utada, 1974; Pisciotto, 1981). In the Monterey Shale, ISAACS (1981) presented a lateral variation of the silica phase, which she ascribed to difference in post-depositional temperature and in burial depth. However, unless affected by igneous intrusion or geothermal effect as reported by MURATA et al. (1979), normal siliceous sediments are considered to become hard and chemically closed for roughly $20 \mathrm{Ma}$ after deposition. Our previous investigation showed this figure to be acceptable for the Jurassic siliceous shale of Hida-Kanayama.

The same interpretation is reasonably put forward on the time difference of about $30 \mathrm{Ma}$ observed in set (c). But this kind of chronological discussion cannot be made for set (b), Jurassic siliceous shale in Unuma, because the fossil age is apparently younger than the isotopic age; in other words, the deposition age is younger than the diagenesis age. This inconsistent result is explained by i) the time scale for Jurassic and older ages is not reliable and should be revised, ii) the radiolarian biostratigraphical zonation is not yet so accurate and should be examined more globally, or iii) the isotopic age may approximate the time of deposition or reflect the age of provenance in this case by unknown reason. These problems are poorly understood to date and remain to be solved in future.

$\mathrm{K}$-Ar whole-rock ages of sedimentary rocks are controlled by various factors; the existence of such a detrital mineral as sericite causes an accumulation of excess Ar which results in an isotopic age older than the deposition age. On the other hand, if $\mathrm{K}-\mathrm{Ar}$ system is related only with a newly formed mineral of authigenic origin, the $\mathrm{K}-\mathrm{Ar}$ whole-rock age represents the time of formation of this mineral. In the siliceous shale in set (a) of Hida-Kanayama (Shibata and Mizutani, 1980), the K-Ar whole-rock ages of four samples among six are identical with the $\mathrm{Rb}-\mathrm{Sr}$ whole-rock isochron age; this implies that both $\mathrm{K}-\mathrm{Ar}$ and $\mathrm{Rb}-\mathrm{Sr}$ systems of the siliceous shale became closed at the same time. There are, however, two samples having much older K-Ar whole-rock ages. Judging from the textural properties of the samples, we ascribed these older ages to the detrital minerals contained in them.

The same idea is acceptable here for the explanation of the $\mathrm{K}-\mathrm{Ar}$ age of the Triassic bedded chert of Unuma in set (c) for which the $\mathrm{K}-\mathrm{Ar}$ and $\mathrm{Rb}-\mathrm{Sr}$ ages agree with each other. As already described, conodont elements extracted from this bedded chert are light gray and not transparent. According to the color alteration of conodont discussed by EPSTEIN et al. (1977), it is very likely that the bedded chert has not been subjected to any thermal event after the end of diagenesis, say, for about $210 \mathrm{Ma}$. Both $\mathrm{K}-\mathrm{Ar}$ and $\mathrm{Rb}-\mathrm{Sr}$ systems of the Triassic bedded 
chert became closed at this time, and the total system has been unchanged. But the $\mathrm{K}-\mathrm{Ar}$ age of the siliceous shale of Unuma in set (b), $151 \mathrm{Ma}$ and $152 \mathrm{Ma}$, is not explained by a process of sedimentation or ensuing burial, since the $\mathrm{Rb}-\mathrm{Sr}$ whole-rock age is older than the $\mathrm{K}-\mathrm{Ar}$ ages. Under the microscope, no trace of thermal effect is observed in the siliceous shale of Unuma, and hence the K-Ar age does not reflect any igneous activity. The age may be ascribed to a tectonic event, although an actual effect of such process upon the $\mathrm{K}-\mathrm{Ar}$ system has been scarcely known so far.

In spite of the occurrence of the Jurassic siliceous shale contact to the Triassic bedded chert, the Jurassic siliceous shale has two different isotopic ages, about $180 \mathrm{Ma}$ and about 150 Ma. This time-relation is explained possibly by the following successive events: 1) deposition of the Triassic chert, 2) the end of its chemical diagenesis (about $210 \mathrm{Ma}$ ), 3) deposition of the Jurassic shale, 4) the end of its chemical diagenesis (about $180 \mathrm{Ma}$ ), 5) the end of unknown disturbance only for the Jurassic shale (about $150 \mathrm{Ma}$ ), and 6) final coalescing of both formations (no effect on the isotopic compositions, age unknown).

The Jurassic and the Triassic age data discussed in this paper have been obtained from samples within the Jurassic and the Triassic stratigraphic sequence shown in Fig. 2, respectively. Strictly speaking, the deposition age of the lower part of a succession is obviously older than that of the upper one, the difference of which should be involved practically in the measurement error. Based on the biostratigraphic study of the Deep Sea Drilling Project, Leg 41, LANCELOT et al. (1978) described the accumulation rate of the Early Cretaceous variegated claystone and of the chert-bearing parts of the lower Neocomian to have been about $12 \mathrm{~m} / \mathrm{Ma}$ and $4.8 \mathrm{~m} / \mathrm{Ma}$, respectively. When these values are referred to, the whole of the stratigraphic succession in Fig. 2 is considered to have been formed during a few million years. Even if the geochronological measurement is ideally accurate, a time-span of a few million years is inevitably involved in the uncertainty of resultant age determination.

The initial ${ }^{87} \mathrm{Sr} /{ }^{86} \mathrm{Sr}$ ratio of each set of samples reported in this paper is higher than that of the contemporaneous marine water. Undoubtedly, sediments were not equilibrated with the water for $\mathrm{Sr}$ isotopes at the end of diagenesis, the isotopic composition being controlled by the overall average of the ${ }^{87} \mathrm{Sr} /{ }^{86} \mathrm{Sr}$ ratio of detrital materials as well as of the $\mathrm{Rb} / \mathrm{Sr}$ ratio and age. The high value of ${ }^{87} \mathrm{Sr} /{ }^{86} \mathrm{Sr}$ ratio strongly suggests the existence of older landmass in a source area from which detrital materials were derived. In three sets of samples mentioned above, the ${ }^{87} \mathrm{Sr} /{ }^{86} \mathrm{Sr}$ initial ratios are (a) 0.7155 \pm 0.0008 , (b) $0.71011 \pm 0.00036$, and (c) $0.71325 \pm 0.00020$. The highest one is found in the Upper Jurassic siliceous shale. Perhaps, the older landmass, probably of Precambrian age as reported by Shibata et al. (1971) and Shibata and ADACHI (1974), were most vastly exposed in the source area at this time. It is also beyond doubt that such fine-grained detrital materials were mixed in the Triassic bedded chert, and they are responsible for concentrations of rareearth elements. Chondrite-normalized rareearth distribution patterns described by SHIMIZU and MASUDA (1977) also show the mixing of continental source material in the Triassic chert of Central Japan as displayed by no Ceanomaly and by small negative Eu-anomaly.

The isotopic compositions of sedimentary rocks provide varied information regarding the geological history of the rocks. Two sets of samples described in this paper and one quoted from our previous work offer a telling example from Central Japan.

Acknowledgements-Dr. K. NAKASEKO of Osaka University and Drs. K. ICHIKAWA and A. YAO of Osaka City University gave us fruitful discussions on the radiolarian biostratigraphy. Dr. T. KOIKE of Yokohama National University helped us in the identification of conodonts. Mr. S. UCHIUMI of the Geological Survey of Japan assisted us in K-Ar dating. A part of this study was financially supported by the Grant-in-Aid for Cooperative Research of the Ministry of Education, Science and Culture (Grant No. 57340047). We are much indebted to all of them and would like to record our sincere thanks. 


\section{REFERENCES}

ARMSTRonG, R. L. and MCDOWALl, W. G. (1974) Proposed refinement of the Phanerozoic time scale. Abs. Intl. Mtg. Geochron. Cosmochron. Isotope Geology (Paris).

BISCAYE, P. E. and DASCH, E. J. (1971) The rubidium, strontium, strontium-isotope system in deep-sea sediments: Argentine Basin. J. Geophys. Res. 76, 5087-5096.

Cordani, U. G., Kawashita, K. and Filho, A. T. (1978) Applicability of the rubidium-strontium method to shales and related rocks. Contributions to the Geologic Time Scale, ed. by G. V. COHEE, M. F. GlaesSNER and H. D. HedberG, Am. Assoc. Petrol. Geol. Studies in Geology No. 6, 93-117.

DASCH, E. J. (1969) Strontium isotopes in weathering profiles, deep-sea sediments, and sedimentary rocks. Geochim. Cosmochim. Acta 33, 1521-1552.

Dumitrica, P., KozUR, H. and Mostler, H. (1980) Contribution to the radiolarian fauna of the Middle Triassic of the Southern Alps. Geol. Palaeont. Mitt. Innsbruck 10, 1-46.

EPSTEIN, A. G., EPSTEIN, J. B. and HARRIS, L. D. (1977) Conodont color alteration - an index to organic metamorphism. U. S. Geol. Survey, Prof. Paper 995, 27pp.

HAYASHI, T. and INOUE, S. (1962) Sedimentary structures in the southern part of the Mino massif, central Japan. Bull. Aichi Gakugei Univ. 11, 79-90.

ICHIKAWA, K. and YAO, A. (1976) Two new genera of Mesozoic cyrtoid radiolarians from Japan. Progress in Micropaleontology, 110-117.

ISAACS, C. M. (1981) Porosity reduction during diagenesis of the Monterey Formation, Santa Barbara Coastal area, California. The Monterey Formation and related siliceous rocks of California, ed. by R. E. GARRISON et al., Soc. Econ. Paleont. Mineral., Pacific Section, Sp. Pub. 257-271.

KonDO, N. and ADACHI, M. (1975) Mesozoic strata of the area north of Inuyama, with special reference to the Sakahogi conglomerate (in Japanese with English abstract). J. Geol. Soc. Jpn. 81, 373-386.

LANCELOT, Y. and The Shipboard Scientific Party (1978) Site 367: Cape Verde Basin. Init. Rept. Deep Sea Drilling Project 41, 163-232.

MizUTANI, S. (1970) Silica minerals in the early stage of diagenesis. Sedimentology 15, 419-436.

MiZUTANI, S. (1977) Progressive ordering of cristobalitic silica in the early stage of diagenesis. Contr. Mineral. Petrol. 61, 129-140.

MIZUTANI, S. (1981) A Jurassic formation in the HidaKanayama area, Central Japan. (in Japanese with English appendix and description) Bull. Mizunami Fossil Museum No. 8, 147-190.
MiZUTANI, S., HATTORI, I., ADACHI, M., WAKITA, K. OKAMURA, Y., Kido, S., KaWAGUCHI, I. and KomMA, S. (1981a) Jurassic formations in the Mino area, central Japan. Proc. Japan Acad. 57, 194-199.

MiZutaNI, S., IMOTO, N., YAO, A., ICHIKAWA, K., ISHIDA, K., NAKAZAWA, K., OTSUKA, T., SHIMIZU, D. and SUYARI, K. (1981b) Triassic bedded chert and associated rocks in the Inuyama area, central Japan. The Second International Conference on Siliceous Deposits in the Pacific Region. ed. by A. InIMA, Guides to Excursions, 156-210.

MiZUTANI, S. and KoIKE, T. (1982) Radiolarians in the Jurassic siliceous shale and in the Triassic bedded chert of Unuma, Kagamigahara City, Gifu Prefecture, central Japan. (in Japanese with English abstract) News of Osaka Micropaleontologists, Sp. Publ. No. 5, 117-134.

Murata, K. J., DibBleE, T. W. Jr. and DRINKWATER, J. L. (1979) Thermal effects of large bodies of intrusive serpentinite on overlying Monterey Shale, southern Diablo Range, Cholame Area, California. U. S. Geol. Surv., Prof. Paper 1082, 8 pp.

PessaGno, E. A. Jr. and Blome, C. D. (1980) Upper Triassic and Jurassic Pantanelliinae from California, Oregon and British Columbia. Micropaleontology 26, 225-273.

Peterman, Z. E., Hedge, C. E. and Tourtelot, H. A. (1970) Isotopic composition of strontium in sea water throughout Phanerozoic time. Geochim. Cosmochim. Acta 34, 105-120.

PisciotTo, K. A. (1981) Diagenetic trends in the siliceous facies of the Monterey Shale in the Santa Maria region, California. Sedimentology 28, 547-571.

SHIBATA, K., ADACHI, M. and MIZUTANI, S. (1971) Precambrian rocks in Permian conglomerate from central Japan. J. Geol. Soc. Jpn.77, 507-514.

SHIBATA, K. and ADACHI, M. (1974) Rb-Sr whole-rock ages of Precambrian metamorphic rocks in the Kamiaso conglomerate from central Japan. Earth Planet. Sci. Lett. 21, 277-287.

SHIBATA, K. and MIZUTANI, S. (1980) Isotopic ages of siliceous shale from Hida-Kanayama, central Japan. Geochem. J. 14, 235-241.

SHIMIZU, H. and MASUdA, A. (1977) Cerium in chert as an indication of marine environment of its formation. Nature 266, 346-348.

UTADA, M. (1974) An interpretation of the types of alteration in the Neogene sediments relating to the intrusion of volcano-plutonic complexes, correlating to the calculated temperature patterns. Sci. Paper, Coll. Gen. Educ., Univ. Tokyo 24, 65-77.

YAO, A. (1972) Radiolarian fauna from the Mino belt in the northern part of the Inuyama area, central Japan. Part 1. Spongosaturnalids. J. Geosci., Osaka City Univ. 15, 21-64. 
YORK, D. (1966) Least-square fitting of a straight line. Can. J. Phys. 44, 1079-1086.

\section{APPENDIX}

The exposure of the present study illustrated in Fig. 1 is located at the point denoted as "IN 1" in figure 1 of YAO (1972), or near the location described as "VARIEGATED BEDDED CHERT, MANGANESE CARBONATE NODULES \& LAYERS" in figure 1 of KONDO and ADACHI (1975); in an excursion guide by MIZUTANI et al. (1981b), it is noted as "STOP 1" in their figure 13. In Jurassic formations occurring in the Mino terrane, several radiolarian assemblages have been set forth, among which Unuma echinatus Assemblage described by MIZUTANI et al. (1981a) was established for a radiolarian association in siliceous shale and manganese carbonate rock in this outcrop.

Samples treated in this paper shown in Figures and Tables in the text are briefly described.

\section{JURASSIC SILICEOUS SHALE}

SMU01: Gray siliceous shale, consisting mainly of cryptocrystalline silica and clayey material; slightly laminated, intercalating a thin $(0.2 \mathrm{~mm})$ layer composed of fine grains of quartz, altered mica and altered feldspar. Minute flakes of illite sparsely observed. Abundant in radiolarian skeletons, whose inner chamber is always filled with microcrystalline chlorite.

SMU02: Grayish brown siliceous mudstone; radiolarian remains, $5 \%$ or less in volume, embedded in matrix of cryptocrystalline silica and clay. Their chambers filled with microcrystalline chlorite. Minute flakes of illite, sparsely present. Veinlets filled with anhedral quartz and chlorite are rarely observed.

SMU03: Grayish brown siliceous mudstone, containing radiolarian skeletons whose chambers are filled with chlorite or chalcedonic quartz. Very fine-grained angular quartz, altered feldspar and altered biotite are rarely observed. Minute flakes of sericite are sporadically present. Embryonic development of microstylolitic suturing occasionally seen.

SMU04: Grayish brown siliceous shale carrying abundant spherulitic grains of rhodochrosite, about $0.5 \mathrm{~mm}$ in diameter. The carbonate spherules come to contact with each other with microstylolitic suture, or they are embedded in very fine-grained clayey matrix. Radiolarian fossils are sometimes included in the spherule, but very rare in clayey matrix. Fine and angular grains (less than $0.02 \mathrm{~mm}$ in diameter) of quartz and minute flakes of illite are sparsely observed.

SMU05: Dusky brown siliceous shale, finely laminated; radiolarian skeletons, partly being in alignment in a lamina, occupy about $30 \%$ in volume. Their chambers are filled with chlorite, and sometimes with chalcedonic quartz. A laminated layer, $0.2 \mathrm{~mm}$ thick, composed chiefly of fine-grained angular quartz is interbedded within matrix of cryptocrystalline silica and clayey material.

SMU07: Grayish brown siliceous shale, finely laminated. Radiolarian remains, $10 \%$ or less in volume, are contained in matrix of cryptocrystalline silica and clayey material. Minute flakes of sericite and fine-grained quartz are sporadically found. A thin lamina of finegrained angular quartz is also observed.

SMU08: Grayish brown siliceous shale, containing a small amount (less than $5 \%$ in volume) of radiolarian remains in matrix of cryptocrystalline silica and clayey material. Slightly laminated. Veinlets, about $0.1 \mathrm{~mm}$ in width, filled with chlorite, or with quartz and chlorite, are sparsely found.

SMU09: Dark gray siliceous shale, slightly laminated. Radiolarian skeletons, filled with chlorite, occupy $5 \%$ or less in volume. Very fine-grained angular quartz is scarcely found.

SMU10: Medium gray manganese carbonate rock. Rhodochrosite spherules (about $0.5 \mathrm{~mm}$ in diameter), more than $60 \%$ in volume, are scattered in clayey matrix. Radiolarian remains abundant both-in the spherules and in matrix, attaining more than $60 \%$ in volume. They are almost completely preserved especially in the carbonate spherules, whereas skeletons replaced with carbonate are found in places of clayey matrix.

\section{TRIASSIC BEDDED CHERT}

SMT01: Grayish red chert containing abundant radiolarian remains (20-40\% in volume). Chambers of the fossils are invariably filled with microcrystalline anhedral quartz or chalcedonic quartz. Fine veinlets of quartz, or of quartz and chlorite are found.

SMT02: Grayish red chert. Radiolarian skeletons (20\%) and sponge spicules (5\%) are contained, both completely converted to microcrystalline anhedral quartz. Radiolarian chambers are filled with microcrystalline or cryptocrystalline quartz. Fine veinlets of chlorite, or of quartz and chlorite are sparsely found.

SMT03: Grayish red shale. This is an argillaceous part of bedded chert, composed mainly of very finegrained clayey material, intercalating thin $(0.5 \mathrm{~mm}$ thick) layers, rich in radiolarian remains whose chambers are always filled with microcrystalline anhedral quartz and chalcedonic quartz.

SMT04: Grayish red shale. This is also an argillaceous part of bedded chert. Radiolarian skeleton is very rare, less than $1 \%$ in volume; the chambers are filled with chlorite.

SMT05: Grayish red chert, containıng partly more than $60 \%$ of radiolarian remains, and intercalating a thin $(1.5 \mathrm{~mm})$ layer composed entirely of microcrystalline clayey material and cryptocrystalline silica in which 
no radiolarian fossil is found. All of the radiolarian chambers are filled with microcrystalline anhedral quartz or chalcedonic quartz.

SMT06: Medium gray chert made up of alternating layers (several $\mathrm{mm}$ in width) of laminae rich and poor in radiolarian remains. Radiolarian chambers are filled with microcrystalline anhedral quartz and/or chalcedonic quartz. Veinlets, composed of quartz, or of quartz and chlorite, developed almost perpendicular to the bedding plane.

SMT07: Black chert. Rich in radiolarian remains,
$40-50 \%$ in volume, embedded in matrix of semi-transparent light gray brown material and of cryptocrystalline silica. Fine irregularly cross-cutting veinlets of quartz present.

1704: Grayish red chert, composed chiefly of microcrystalline silica and clayey material, containing about $20 \%$ of radiolarian remains, whose chambers are filled with cryptocrystalline quartz and/or chalcedonic quartz. Fine veinlets of quartz, or of quartz and chlorite are irregularly developed. 